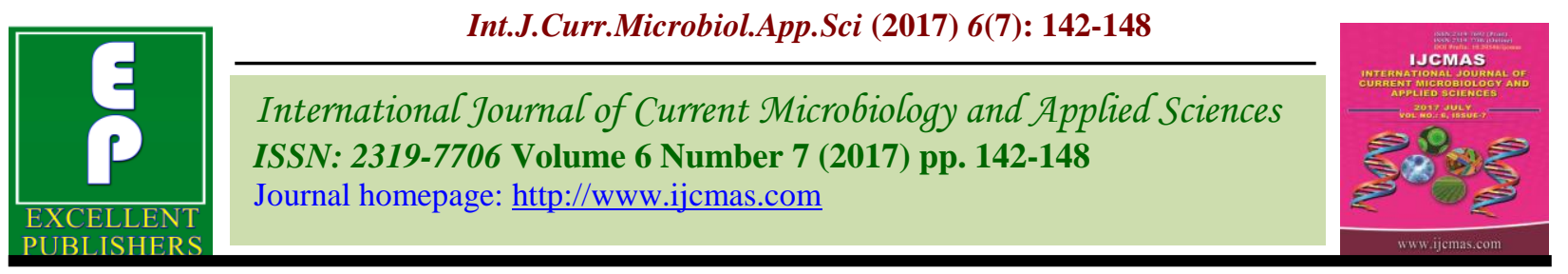

Original Research Article

https://doi.org/10.20546/ijcmas.2017.607.017

\title{
Water Production Parameters and Yield of Rice - Affected by Methods of Transplanting and Irrigation Management Practices
}

\author{
R. Sureshkumar ${ }^{1 *}$ and B.J. Pandian ${ }^{2}$ \\ ${ }^{1}$ Department of Agronomy, ${ }^{2}$ Water Technology Centre, TNAU, \\ Coimbatore-641003, Tamil Nadu, India \\ *Corresponding author
}

\section{A B S T R A C T}

\begin{tabular}{|l|}
\hline Ke y w o r d s \\
Field water tube, \\
Machine \\
transplanting, SRI \\
irrigation, Water \\
productivity, \\
Water use \\
efficiency. \\
\hline Article Info \\
\hline $\begin{array}{l}\text { Accepted: } \\
\text { 04 June } 2017 \\
\text { Available Online: } \\
\text { 10 July } 2017\end{array}$ \\
\hline
\end{tabular}

\section{Keywords}

Field water tube,

Machine

ansplanting, SRI

productivity,

Water use

Article Info

Accepted:

Available Online

\begin{abstract}
A Field experiment was carried out at wetland farm, AC \& RI, Coimbatore during rabi season 2015-2016 to assess the water production parameters and yield of rice under different methods of transplanting and irrigation management practices. The experiment was laid out in strip plot design with replicated thrice. The treatments comprised of four different method of transplanting viz., machine transplanting with $30 \mathrm{~cm} \mathrm{x} 14 \mathrm{~cm}, 30 \mathrm{~cm} \mathrm{x}$ $18 \mathrm{~cm}$, SRI transplanting $(25 \mathrm{~cm} \times 25 \mathrm{~cm})$ and conventional transplanting $(20 \mathrm{~cm} \times 10$ $\mathrm{cm})$, respectively in main plots and four method of irrigation management practices in sub plots viz., continuous submergence of $5 \mathrm{~cm}$, cyclic irrigation management, SRI irrigation management and Field water tube irrigation management. It was found that SRI transplanting registered lower consumption of water with less number of irrigation, higher water use efficiency and water productivity. At the same time, field water tube with intermittent irrigation reduced the total consumption with lesser number of irrigation. This method of irrigation also increased the water use efficiency and water productivity of rice. Machine transplanting $(30 \mathrm{~cm} \times 14 \mathrm{~cm})$ and SRI method of irrigation practice had a profound influence on the grain and straw yield of rice.
\end{abstract}

\section{Introduction}

Conventional transplanting is the most common practice of rice cultivation in South and South East Asia. Transplanting of rice is very labour intensive and at least 30 man days are required to transplant one hectare. Generally, rice growers face the problem of skilled labour shortage at the time of transplanting which results into delayed transplantation, low plant population and eventually low yield (Aslam et al., 2008). Urbanisation, migration of labour from agriculture to non-agriculture sector and increased labour costs are seriously threating the cultivation of crops in general and rice in particular (Yadav et al., 2014).
It is essential to reduce the factor by adopting the appropriate transplanting techniques for rice production to control the competitive prices in local and international markets. Therefore, there is need of alternative methods to replace manual transplanting to tackle the problem of high cost of production and labour scarcity in puddled rice. The mechanical rice transplanting is an alternate and promising option, as it saves labour, ensures timely transplanting and also contributes to higher grain yield.

Rice is one of the greatest water user among cereal crops, consuming about $80 \%$ of the 
total irrigated fresh water resources in Asia. In Asia, with relatively more suitable growing conditions for rice, production has declined due to increasing water stress (Tao et al., 2004). Therefore, it is important to cut down water supply for rice cultivation but without affecting rice yield. So there is an imperative need to find ways to reduce water use, while maintaining high yields in rice cultivation. Since water for rice production has become increasingly scarce water saving is the main issue in maintaining the sustainability of rice production when water resources are becoming scarce (Arif et al., 2012). There are a number of alternatives to continuous flooding of rice. One approach which can be used is intermittent irrigation or alternate wetting and drying (AWD). Instead of keeping rice fields continuously flooded, the adoption of AWD methods means that irrigation water is applied to fields to restore flooded conditions on an intermittent basis, only after a certain number of days have passed since the disappearance of ponded (standing) water (Zhang et al., 2009).

The practice of safe AWD as a mature water saving technology entails irrigation when water depth falls to a threshold depth of below the soil surface. The recommended water management for "safe" (no yield loss) AWD involves applying irrigation (to depth of around $5 \mathrm{~cm}$ ) when the perched water table falls to $15 \mathrm{~cm}$ below the soil surface (Bouman et al., 2007). Several studies have shown that safe AWD reduces water input significantly without penalty in grain yield (Samoy et al., 2008). Kulkarni (2011) reported that using of field water tube in AWD is safe to limit the water use upto $25 \%$ without reduction in rice yield. Compared to famers practice of continuous flooding, safe AWD saves as much as irrigation water $(30 \%)$ without any reduction in yield and increases farmers' income by 30\% (Lampayan, 2013). Hence, the present investigation was taken up to study the effect of different method of transplanting and irrigation management on water production parameters and yield of rice.

\section{Materials and Methods}

A Field experiment was conducted during rabi season of 2015-2016 at Research Farm, Agricultural College and Research Institute, Coimbatore, Tamil Nadu. The experimental site is geographically located in the Western Agro Climatic Zone of Tamil Nadu at $11{ }^{\circ} \mathrm{N}$ latitude, $77^{\circ} \mathrm{E}$ longitude with an altitude of $426.7 \mathrm{~m}$ above mean sea level. The soil of the experimental site was clay loam in texture having alkaline $\mathrm{pH}$ (8.10) and medium organic carbon $(0.62 \%)$, With regard nutrient status, the soil was low in available nitrogen $\left(215.7 \mathrm{~kg} \mathrm{ha}^{-1}\right)$, medium in phosphorus $(15.8$ $\mathrm{kg} \mathrm{ha}^{-1}$ ) and high in potassium (420.8 $\mathrm{kg} \mathrm{ha}^{-1}$ ), respectively. Rice variety $\mathrm{CO}(\mathrm{R}) 50$ with the duration of 135 days was used as test variety.

Experiment was laid out in strip plot design with replicated thrice. The treatments comprised of four different method of transplanting viz., machine transplanting with $30 \mathrm{~cm} \times 14 \mathrm{~cm}\left(\mathrm{M}_{1}\right)$, machine transplanting with $30 \mathrm{~cm} \times 18 \mathrm{~cm}\left(\mathrm{M}_{2}\right)$, SRI transplanting with $25 \mathrm{~cm} \times 25 \mathrm{~cm}\left(\mathrm{M}_{3}\right)$ and conventional transplanting with $20 \mathrm{~cm}$ x $10 \mathrm{~cm}\left(\mathrm{M}_{4}\right)$, respectively in main plots and four method of irrigation management practices in sub plots viz., Farmer practice of continuous submergence of $5 \mathrm{~cm}$ throughout the crop period $\left(\mathrm{I}_{1}\right)$, Cyclic irrigation management of irrigating the field with $5 \mathrm{~cm}$ depth of irrigation one day after disappearance of previously ponded $\left(\mathrm{I}_{2}\right)$, SRI irrigation management of irrigation given @ $2.5 \mathrm{~cm}$ depth after the formation of hair line cracks in the field upto panicle initiation stage and thereafter the irrigation was given immediately after the disappearance of previously ponded water up to 10 days before harvest $\left(\mathrm{I}_{3}\right)$ and field water tube irrigation 
management of maintenance of $5 \mathrm{~cm}$ water level at panicle initiation stage and remaining period irrigation to $5 \mathrm{~cm}$ depth after $15 \mathrm{~cm}$ depletion of ponded water from ground level $\left(\mathrm{I}_{4}\right)$. In order to evaluate the effect of different method of transplanting and irrigation management practices on water use efficiency (WUE), water productivity and yield, the data were statistically analyzed using "Analysis of variance test".

The critical difference at 5\% level of significance was calculated to find out the significance of different treatments over each other (Gomez and Gomez, 1984). The total consumptive use of water, water use efficiency and water productivity were calculated as per the standard procedure.

\section{Total water consumed}

The total water consumed was computed by summing the irrigation water applied and the effective rainfall. Effective rainfall calculated as fifty percentage of total rainfall during the cropping period.

$\mathrm{W}=\mathrm{ND}+\mathrm{Re}$

Where,

$\mathrm{W}=$ Total water consumed in $\mathrm{mm}$

$\mathrm{N}=$ Number of irrigations

$\mathrm{D}=$ Applied water depth for each irrigation (mm)

$\operatorname{Re}=$ Effective rainfall $(\mathrm{mm})$, during the cropping period

\section{Water use efficiency}

Water use efficiency (WUE) was computed using the equation of Viets (1962) and expressed as $\mathrm{kg} \mathrm{ha}^{-1} \mathrm{~mm}^{-1}$. WUE $=\frac{\text { Grain yield }\left(\mathrm{kg} \mathrm{ha}^{-1}\right)}{\text { Total water consumed in }(\mathrm{mm})}$

\section{Water productivity}

Water productivity is a function of total water used and grain yield produced by the crop and expressed in lit. $\mathrm{kg}^{-1}$.

Water Productivity $=\frac{\text { Volume of water used (lit.) }}{\text { Grain yield }\left(\mathrm{kg} \mathrm{ha}^{-1}\right)}$

\section{Results and Discussion}

\section{Effect on consumptive water use, number of irrigation and water saving percentage}

The amount of water required meeting the demands of evapotranspiration and metabolic activities of rice together constitute the consumptive water use, which includes the effective rainfall during the growing season (Fig. 1). Among various method of transplanting, SRI transplanting registered lower consumptive use of water $(907 \mathrm{~mm})$, less number of irrigation (15) and higher percentage of water saving (34.2\%). Whereas, higher consumptive use of water (1095 mm), number of irrigation (19) and lower percentage of water saving $(27.3 \%)$ was observed with conventional transplanting. As such, the farmers' practice of irrigation consumed more water of $1194 \mathrm{~mm}$ with higher number of 23 irrigation. On the contrary, lesser consumptive use of water (804 mm) was observed under field water tube irrigation at $15 \mathrm{~cm}$ drop of water table was due to lesser number of irrigations (12) and recorded higher water saving percentage of $41.7 \%$. Similar observations were also reported by Ngo Thanh Son et al., (2008).

\section{Effect on water use efficiency (WUE) and water productivity (WP)}

The higher water use efficiency (WUE) and water productivity (WP) can be increased either by increasing yield or by maintaining the yield level with reduced quantity of water 
input. Among various method of transplanting, SRI transplanting registered higher WUE of $6.7 \mathrm{~kg} \mathrm{ha}^{-1} \mathrm{~mm}^{-1}$ and WP of 1533 lit. $\mathrm{kg}^{-1}$ (Table 1). Whereas, lower WUE and WP found with conventional method of transplanting.

On the other hand, reduction in consumptive water use under field water tube irrigation at $15 \mathrm{~cm}$ drop of water table coupled with the maintenance of yield at an optimum level increased the WUE and WP. The higher WUE of $6.9 \mathrm{~kg} \mathrm{ha}^{-1} \mathrm{~mm}^{-1}$ and WP of 1467 lit. $\mathrm{kg}^{-1}$ was observed under field water tube irrigation treatment and was on par with SRI method of irrigation $\left(6.6 \mathrm{~kg} \mathrm{ha}^{-1} \mathrm{~mm}^{-1}\right.$ and 1559 lit. $\mathrm{kg}^{-1}$, respectively). The increased water use efficiency obtained under these treatments could be attributed due to optimum need based irrigation using monitoring device i.e. field water tube coupled with increased grain yield levels. The higher consumptive use with more frequent irrigations without corresponding increase in grain yields could have led to decreased WUE under farmers' practice of irrigation practice. This is in agreement with the findings of Bouman et al. (2007).

\section{Effect on grain and straw yield}

Method of transplanting and irrigation management practices had a profound influence on the grain and straw yield of rice and is shown in table 2. Machine transplanted rice $(30 \mathrm{~cm} \times 14 \mathrm{~cm})$ recorded higher grain yield $\left(6065 \mathrm{~kg} \mathrm{ha}^{-1}\right)$ and straw yield $(7237 \mathrm{~kg}$ $\mathrm{ha}^{-1}$ ) and was on par with SRI method of transplanted rice $\left(5952\right.$ and $7006 \mathrm{~kg} \mathrm{ha}^{-1}$, respectively). Higher yield realized with mechanized transplanting might be due to the use of younger seedlings, which preserves a potential for higher tillering and rooting. Better vegetative growth and assimilate translocation leads to increased number of panicles per square meter and fertile grains per panicle resulting in higher grain and straw yield. Machine transplanting recorded higher grain yield and was at par with SRI square transplanting was also reported by Kumar (2014) and Sangeetha et al., (2015).

Fig.1 Effect of different transplanting methods and water management practices on consumptive water use $(\mathrm{mm})$, number of irrigation and water saving percentage of rice

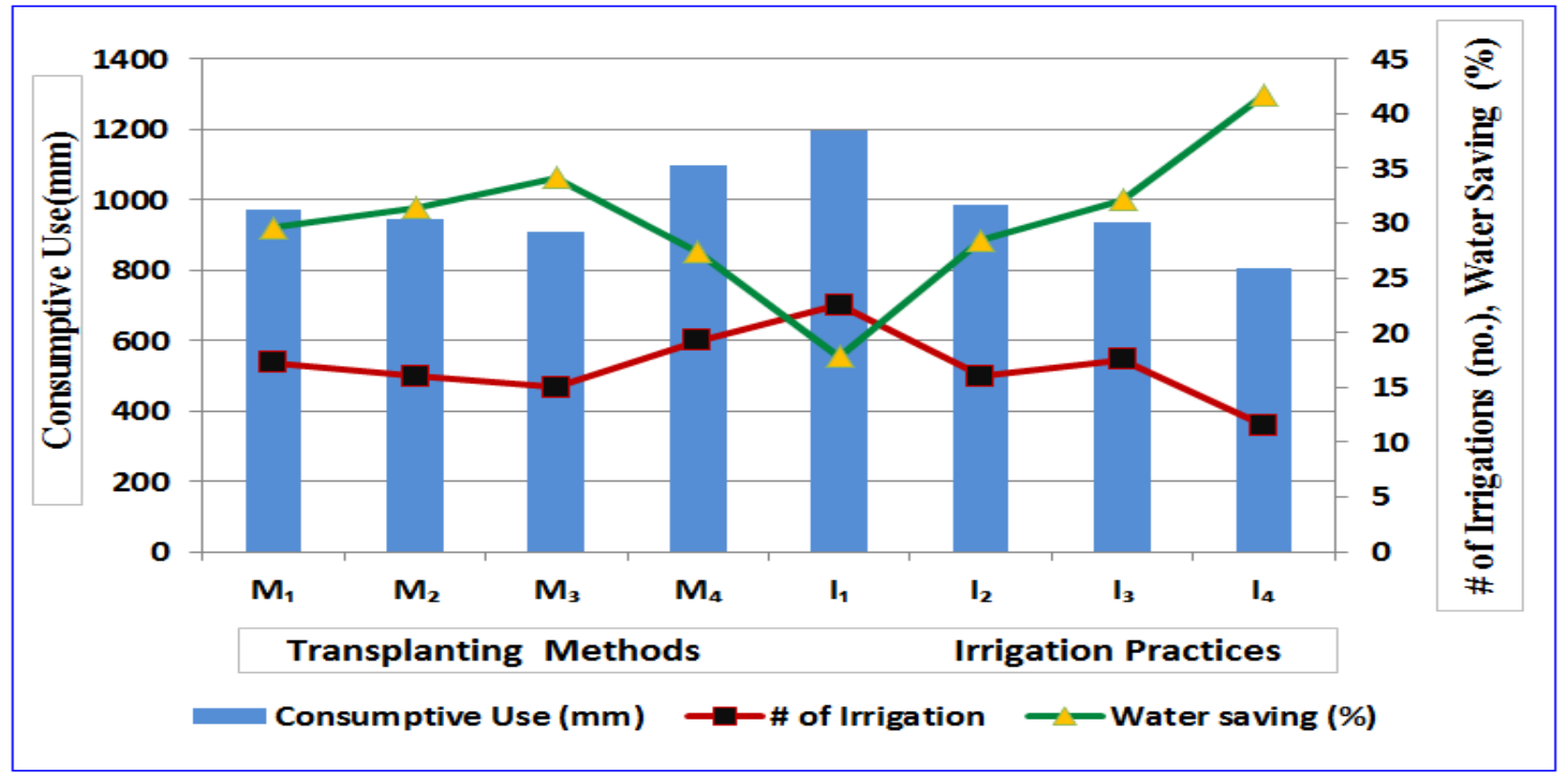


Table.1 Effect of different transplanting and water management practices on water use efficiency $\left(\mathrm{kg} \mathrm{ha}^{-1} \mathrm{~mm}^{-1}\right)$ and water productivity (lit. $\mathrm{kg}^{-1}$ )

\begin{tabular}{|c|c|c|c|c|c|c|c|c|c|c|c|}
\hline \multirow{2}{*}{ Treatment } & \multicolumn{4}{|c|}{ Water Use Efficiency $\left(\mathbf{k g ~ h}^{-\mathbf{1}} \mathbf{m m}^{-\mathbf{1}}\right)$} & \multicolumn{5}{c|}{ Water Productivity $\left(\mathbf{l i t}_{\mathbf{~ k g}}^{\mathbf{- 1}}\right)$} \\
\cline { 2 - 14 } & $\mathbf{M}_{\mathbf{1}}$ & $\mathbf{M}_{\mathbf{2}}$ & $\mathbf{M}_{\mathbf{3}}$ & $\mathbf{M}_{\mathbf{4}}$ & $\mathbf{M e a n}$ & & $\mathbf{M}_{\mathbf{1}}$ & $\mathbf{M}_{\mathbf{2}}$ & $\mathbf{M}_{\mathbf{3}}$ & $\mathbf{M}_{\mathbf{4}}$ & Mean \\
\hline $\mathbf{I}_{\mathbf{1}}$ & 4.8 & 4.6 & 5.2 & 3.8 & $\mathbf{4 . 6}$ & $\mathbf{I}_{\mathbf{1}}$ & 2090 & 2174 & 1913 & 2627 & $\mathbf{2 2 0 1}$ \\
\hline $\mathbf{I}_{\mathbf{2}}$ & 6.4 & 6.0 & 6.4 & 5.1 & $\mathbf{6 . 0}$ & $\mathbf{I}_{\mathbf{2}}$ & 1571 & 1661 & 1552 & 1974 & $\mathbf{1 6 9 0}$ \\
\hline $\mathbf{I}_{\mathbf{3}}$ & 7.1 & 6.8 & 7.4 & 5.0 & $\mathbf{6 . 6}$ & $\mathbf{I}_{\mathbf{3}}$ & 1413 & 1467 & 1351 & 2004 & $\mathbf{1 5 5 9}$ \\
\hline $\mathbf{I}_{\mathbf{4}}$ & 7.3 & 6.9 & 7.6 & 5.7 & $\mathbf{6 . 9}$ & $\mathbf{I}_{\mathbf{4}}$ & 1366 & 1445 & 1316 & 1742 & $\mathbf{1 4 6 7}$ \\
\hline Mean & $\mathbf{6 . 4}$ & $\mathbf{6 . 1}$ & $\mathbf{6 . 7}$ & $\mathbf{4 . 9}$ & & & $\mathbf{1 6 1 0}$ & $\mathbf{1 6 8 7}$ & $\mathbf{1 5 3 3}$ & $\mathbf{2 0 8 7}$ & \\
\hline & $\mathbf{M}$ & $\mathbf{I}$ & $\mathbf{M}$ at I & $\mathbf{I}$ at $\mathbf{M}$ & & & $\mathbf{M}$ & $\mathbf{I}$ & $\mathbf{M}$ at I & $\mathbf{I}$ at $\mathbf{M}$ & \\
\hline SEd & 0.2 & 0.2 & 0.3 & 0.3 & & & 44 & 49 & 80 & 83 & \\
\hline CD $(\mathbf{p}=\mathbf{0 . 0 5})$ & 0.4 & 0.5 & NS & NS & & & 108 & 120 & NS & NS & \\
\hline
\end{tabular}

Table.2 Effect of different transplanting and water management practices on grain yield $\left(\mathrm{kg} \mathrm{ha}^{-1}\right)$ and straw yield $\left(\mathrm{kg} \mathrm{ha}^{-1}\right)$ of rice

\begin{tabular}{|c|c|c|c|c|c|c|c|c|c|c|c|}
\hline \multirow{2}{*}{ Treatment } & \multicolumn{5}{|c|}{ Grain Yield $\left(\mathrm{kg} \mathrm{ha}^{-1}\right)$} & & \multicolumn{5}{|c|}{ Straw Yield $\left(\mathrm{kg} \mathrm{ha}^{-1}\right)$} \\
\hline & $\mathbf{M}_{1}$ & $\mathbf{M}_{2}$ & $\mathbf{M}_{3}$ & $\mathbf{M}_{4}$ & Mean & & $\mathbf{M}_{1}$ & $\mathbf{M}_{2}$ & $\mathbf{M}_{3}$ & $\mathbf{M}_{4}$ & Mean \\
\hline $\mathbf{I}_{1}$ & 5675 & 5276 & 5562 & 5246 & 5440 & $I_{1}$ & 6734 & 6116 & 6493 & 6147 & 6373 \\
\hline$I_{2}$ & 6142 & 5685 & 5978 & 5613 & 5855 & $\mathbf{I}_{2}$ & 7361 & 6495 & 6999 & 6423 & 6819 \\
\hline$I_{3}$ & 6566 & 6150 & 6476 & 5170 & 6091 & $I_{3}$ & 7800 & 7371 & 7769 & 6041 & 7245 \\
\hline$I_{4}$ & 5878 & 5467 & 5790 & 4937 & 5518 & $\mathbf{I}_{4}$ & 7051 & 6280 & 6765 & 5917 & 6503 \\
\hline Mean & 6065 & 5645 & 5952 & 5242 & & & 7237 & 6566 & 7006 & 6132 & \\
\hline & $\mathbf{M}$ & $\mathbf{I}$ & M at I & I at $M$ & & & $\mathbf{M}$ & I & M at I & I at $M$ & \\
\hline SEd & 94 & 120 & 188 & 202 & & & 110 & 141 & 221 & 238 & \\
\hline$C D(p=0.05)$ & 230 & 293 & 410 & 449 & & & 269 & 345 & 483 & 529 & \\
\hline
\end{tabular}

Irrigation management practices greatly influenced the rice grain yield. Among the Irrigation management practices, SRI method of irrigation recorded higher grain and straw yield of 6091 and $7245 \mathrm{~kg} \mathrm{ha}^{-1}$, respectively. This was on par with cyclic irrigation management. The increased yields under SRI method of irrigation might be due to favourable growing and nutrition supply environment and with increased uptake of nutrients under SRI method of irrigation which lead the plants with superior growth and the favourable growth traits enhanced the yield attributing characters with higher source to sink conversion, which in turn resulted in higher grain and straw yield. This is in line with findings of Thiyagarajan et al., (2002) and Geethalakshmi et al., (2009). On the other hand, need based water management practice of field water tube irrigation at $15 \mathrm{~cm}$ drop of water table also created same condition as that of SRI method of irrigation with reduced irrigation which recorded increased level of yield. This was supported by Bouman et al., (2007) and Oliver et al., (2008).

Interaction found to exist between method of transplanting and irrigation management practices with respect to rice grain yields. At all method of transplanting, the SRI method of irrigation registered higher grain and straw yields except in conventional transplanting. At all the irrigation management practices, machine transplanting with $30 \mathrm{~cm} \mathrm{x} 14 \mathrm{~cm}$ registered higher grain yield in rice. In combination also, these two treatments produced higher grain yields indicated that the physico-chemical environment prevailed under these treatment combinations produced favourable growth and yield attributes, which in turn reflected on grain and straw yields. 
In this experiment it was found that SRI transplanting registered lower consumptive use of water with less number of irrigation. This treatment also recorded higher percentage of water saving, water use efficiency and water productivity. Use of younger seedlings and wider spacing proved to be better than other combinations with different method of water management. Even under normal cultivation, adoption of wider spacing gave more satisfactory yield than closer spacing. At the same time, field water tube with intermittent irrigation was observed to be a suitable method for reducing total consumptive use of water with lesser number of irrigation. This method of irrigation also increased the water use efficiency and water productivity of rice. Machine transplanting $(30 \mathrm{~cm} \times 14 \mathrm{~cm})$ and SRI method of irrigation practice had a profound influence on the grain and straw yield of rice.

\section{References}

Arif, C., Setiawan, B.I., Mizoguchi, M. and Doi, R. 2012. Estimation of water balance components in paddy fields under non-flooded irrigation regimes by using excel solver. J. Agron., 11(2): 5359.

Aslam, M., Hussain, S., Ramzan, M. and Akhter, M. 2008. Effect of different stand establishment techniques on rice yields and its attributes. J. Anim. Pl. Sci., 18(2-3): 80-82.

Bouman, B.A.M., Humphrey, E., Tuong, T.P. and Barker, R. 2007. Rice and water. Advances in Agronomy, 92 (4): 187237.

Geethalakshmi, V., Ramesh, T., Azhapalamuthirsolai and Lakshmanan, A. 2009. Productivity and water usage of rice as influenced by different cultivation systems. Madras Agric. J., 96 (7-12): 349-352.

Gomez, K.A and Gomez, A.A. 1984. Statistical procedures for agricultural research ( $2^{\text {nd }}$ Ed.), Wiley India Pvt. Ltd., India.

Ngo Thanh Son, B. Rodrigo, Badayos, B. Pearl. Sanchez, C. Pompe, Sta, Cruz, Nguyen Van Dung and Nguyen Huu Thanh. 2008. Water productivity and soil Chemical properties under varying water regimes on spring Rice (Oryza sativa L.) in Hanoi Vietnam. Phillipine J. of Crop Science, 33 (3): 56-70.

Kulkarni, S. 2011. Innovative technologies for water saving in irrigated agriculture. Int. J. Water Resources and Arid Environ, 1(3): 226-231.

Kumar, N.S. 2015. Enhancing Rice Productivity by Adopting Different Cultivation Methods, Int. J. Pure App. Biosci. 3(6): 76-80.

Lampayan, R.M. 2013. Smart water technique for rice. http://www.eiard.org/keydocuments /impact-case-studies/2013. Accessed 5 June 2013.

Oliver, M.M.H., Talukder, M.S.U. and Ahmed, M. 2008. Alternate wetting and drying irrigation for rice cultivation. $J$. Bangladesh Agril. Univ. 6 (2): 409-414.

Samoy, K.C., Cantre, M.A.C., Corpuz, A.A., de Dios, J.L., Sibayan E.B. and Cruz, R.T. 2008. Controlled irrigation in leaf color chart-based and growth stage-base nitrogen management. In: Proc. of the $38^{\text {th }}$ Annual Scientific Conference of the Crop Science Society of the Philippines, 12-16 May 2008, Iloilo City, Philippines, p 34.

Sangeetha, C., Velayutham, A., Thavaprakaash, N. and Chinnusamy, C. 2015. Crop establishment and weed managment effects on rice productivity and weed dynamics. Indian Journal of Weed Science, 47(1): 6-10.

Tao, F. M., Yokozawa, Z., Zhang, Y., Hayashi, H. G. and Fu, C. 2004. Variability in climatology and agricultural production in China in association with the East Asia summer 
monsoon and El Niño South Oscillation. Climate Res., 28: 23-30.

Thiyagarajan, T.M., Velu, V., Ramasamy, S., Durgadevi, D., Govindarajan, K., Priyadarshini, R., Sudhalakshmi, C., Senthilkumar, K. Nisha, P.T., Gayathry, G., Hengsdijk, H. and Bindraban, P.S. 2002. Effect of SRI practices on hybrid rice performance in Tamil Nadu, India. In: Bouman, B. A. S., Hengsdijk, H., Hardy, B., Humphrey, E., Tuong, T.P. and Barker, R. 2007. Rice and water. Advances in Agronomy, 92 (4): 187237.
Viets, F.G. 1962. Fertilizers and the efficient use of water. Adv. Agron., 14: 223-264.

Yadav, S. K., Singh, D. K. and Rani, M. 2014. Interaction effect of weed management practices, brown manuring and nitrogen levels on yield of direct seeded rice and growth of weeds. Green Farming, 5(1): 46-50.

Zhang, H., Xue, Y., Wang, Z., Yang, J. and Zhang, J. 2009. An alternate wetting and moderate soil drying regime improves root and shoot growth in rice. Crop Sci., 49: 2246-2260.

\section{How to cite this article:}

Sureshkumar, R. and Pandian, B.J. 2017. Water Production Parameters and Yield of Rice Affected by Methods of Transplanting and Irrigation Management Practices. Int.J.Curr.Microbiol.App.Sci. 6(7): 142-148. doi: https://doi.org/10.20546/ijcmas.2017.607.017 